KRZYSZTOF TRZCIŃSKI

Uniwersytet Jagielloński

ORCID: 0000-0003-0268-6344

krzysztof.trzcinski@uj.edu.pl

\title{
HYBRYDOWE POWER-SHARING. KONCEPCJA I INSTYTUCJE
}

\section{Hybrid Power-Sharing: Concept and Institutions}

This paper discusses the theory of the so-called hybrid power-sharing (HPS). HPS is - along with consociationalism and centripetalism - one of the main models of power-sharing (PS) political systems, which have been implemented especially in some multi-ethnic and multi-religious states. PS-type systems provide specific institutions that may reduce conflicts between social segments like ethnic groups or religious communities and between them and the central government. HPS functions, among others in Nigeria and Indonesia, i.e., states that will soon be among the most important in the world. In the HPS system, mainly centripetal and consociational institutions are combined. This paper's primary purpose is to present new, in-depth HPS conceptual assumptions, defined and systematized based on the cases of Nigeria, Indonesia, Kenya, and Burundi, and to indicate empirical examples of the leading institutions forming HPS in these states.

Keywords: power-sharing, hybrid power-sharing, consociationalism, centripetalism.

\section{WPROWADZENIE}

W artykule tym rozwijam teorię empiryczna hybrydowego power-sharing (HPS), które należy do głównych, obok konsocjonalizmu i centrypetalizmu, modeli systemów politycznych typu power-sharing (PS) ${ }^{1}$

$1 \mathrm{~W}$ artykule tym konsekwentnie stosuje angielskojęzyczny termin power-sharing, który używany jest w międzynarodowym dyskursie naukowym. Jego tlumaczenia na j. polski jako „współrządzenie” i „(współ)dzielenie się władzą" nie zyskały popularności w polskim piśmiennictwie. 
wprowadzonych $\mathrm{w}$ niektórych państwach mających społeczeństwa wielosegmentowe (zwłaszcza wieloetniczne i wieloreligijne), tj. składające się $z$ segmentów społecznych, w których członkostwo opiera się na podstawach askryptywnych i kulturowych. Podstawowe rodzaje tak rozumianych segmentów to narody (w sensie socjologicznym), grupy etniczne oraz wspólnoty religijne i wyznaniowe. Społeczeństwa wielosegmentowe niejednokrotnie określane sa mianem społeczeństw (głęboko, poważnie) podzielonych $z$ powodu konfliktów w stosunkach między tworzacymi je segmentami i między nimi a władzą centralną. Systemy polityczne typu PS, tj. oparte na międzysegmentowym power-sharing (współrządzeniu), służą ograniczaniu tych konfliktów i, w konsekwencji, uzyskiwaniu stabilności politycznej². W takich systemach politycznych następuje zmniejszenie koncentracji władzy i czerpania z niej korzyści przez jakiś dominujący wielkością i (lub) siła segment dzięki dopuszczeniu do udziału we władzy i procesach decyzyjnych elit politycznych wywodzących się $z$ możliwie największej liczby segmentów.

Służa temu specyficzne formalne i nieformalne instytucje (rozumiane jako zespoły regul) przede wszystkim odnoszace się bezpośrednio lub pośrednio do ustanawiania i (lub) funkcjonowania rządu i prezydenta, parlamentu, partii politycznych, systemu wyborczego, decentralizacji i struktury terytorialnej. Instytucje te moga mieć różny stopień ogólności i szczegółowości. I tak np. instytucją może być, $z$ jednej strony, gabinet wielkiej koalicji, a $z$ drugiej, np. jakiś konstytucyjny wymóg. Instytucjom stricte politycznym towarzysza w niektórych państwach wielosegmentowych instytucje PS implementowane $\mathrm{w}$ administracji, wymiarze sprawiedliwości, sektorze bezpieczeństwa, gospodarce, mediach. Choć PS jako system polityczny nie może być rozumiany jedynie jako zbiór pewnych instytucji, to zarazem należy zaznaczyć, że większość innych elementów systemu (struktury, organizacje, świadomość, kultura, relacje, wartości, normy) niż instytucje jest trudna do zmierzenia. Ponadto to instytucje w największym stopniu zmieniaja polityczna rzeczywistość. Instytucje są narzędziami do osiagnięcia stabilności politycznej, zgodnie $z$ założeniami koncepcyjnymi danego modelu PS.

W piśmiennictwie przez lata wyróżniano i przeciwstawiano sobie dwa „klasyczne”, steoretyzowane modele systemów politycznych

2 K. Trzciński, Czym jest stabilność polityczna państwa? „Przegląd Politologiczny” 2015, nr 2, s. 37-47. 
typu PS - konsocjonalizm³ i centrypetalizm ${ }^{4}$. Klasycy teorii PS, Arend Lijphart (konsocjonalista) i Donald L. Horowitz (centrypetalista), nie przywiazywali natomiast większej wagi do możliwości implementowania instytucji obu modeli w ramach tego samego systemu politycznego lub traktowali taki zabieg jako przeciwskuteczny. Tymczasem np. w Nigerii i Indonezji, państwach, które - według różnych raportów - będą wkrótce należeć do najważniejszych w świecie, ukształtowany został w kilku ostatnich dekadach trzeci typ PS - hybrydowe power-sharing - który przyczynił się do skutecznego ograniczenia konfliktów wewnętrznych. W systemie HPS, najkrócej rzecz ujmując, łączone sa instytucje centrypetalizmu i konsocjonalizmu, a czasami dodatkowo wdrażane sa „własne” instytucje hybrydowe, w których zazębiaja się pewne rozwiązania centrypetalne i konsocjonalne. HPS jest odpowiedzią na sytuację, w której aktorzy polityczni państwa wielosegmentowego (szczególnie elity polityczne segmentów i władza centralna) dostrzegaja potrzebę rozwijania systemu politycznego typu PS, ale instytucje samego centrypetalizmu lub konsocjonalizmu $z$ jakichś względów traktuja jako niewystarczające.

Wciaż rozbudowywana teoria PS uzmysławia, że każdy główny model PS opiera się na usystematyzowanych podstawach koncepcyjnych, a zespół jego instytucji nie mieści się w zakresie znaczeniowym takich pojęć, jak: „system rządów” (np. parlamentarny, prezydencki, semiprezydencki), „reżim polityczny” (np. demokracja, reżim hybrydowy, autorytaryzm), „ustrój terytorialny” (np. państwo unitarne, złożone, federacja) czy „forma rządów” (republika, monarchia). Teoria unaocznia również, że zbiór wzajemnie uzupełniających się instytucji symptomatycznych dla konkretnych modeli PS ma charakter systemowy ${ }^{5}$. Modele PS można jednak w pewnych przypadkach traktować nie tyle jako systemy polityczne typu PS, lecz jako podsystemy, na które składają się istniejące $\mathrm{w}$ danym systemie politycznym niezbyt istotne i (lub) często nieliczne instytucje PS ${ }^{6}$.

W literaturze przedmiotu ${ }^{7}$ wskazuje się, że konsocjonalizm jako model pełny lub niemal pełny (system polityczny) lub część rozwia-

\footnotetext{
${ }^{3}$ K. Trzciński, Demokratyzacja w Afryce Subsaharyjskiej. Perspektywa zachodnioafrykańskiej myśli politycznej, Warszawa 2013, s. 29-71.

4 K. Trzciński, Centrypetalizm - integrujacy system polityczny dla państw wieloetnicznych. Zarys teorii empirycznej, „Studia Polityczne” 2015, t. 39, nr 3, s. 183-213.

5 K. Trzcinski, What is Power Sharing? Consociationalism, Centripetalism, and Hybrid Power Sharing, „Studia Polityczne” 2018, t. 46, nr 3, s. 14-18.

6 Rozróżnienie takie $z$ pewnościa nie jest doskonałe i wymaga dalszego dookreślania jego kryteriów.

7 J. McGarry, Classical Consociational Theory and Recent Consociational Performance, „Swiss Political Science Review” 2019, t. 25, z. 4, s. 538; A. McCulloch, Does Moderation
} 
zań konsocjonalnych (podsystem systemu politycznego) istnieje albo istniał m.in. w Belgii, Bośni i Hercegowinie, Burundi, Etiopii, Irlandii Północnej, Kenii, Kolumbii, Libanie (w wariancie konfesjonalnym ${ }^{8}$ ), Macedonii Północnej, Malezji, Niderlandach (w warunkach tzw. filaryzacji ${ }^{9}$ ), RPA, Rwandzie, Sudanie, Sudanie Południowym, Szwajcarii, na Cyprze i Fidżi. Pełny lub niepełny centrypetalizm kojarzony jest lub w różnych okresach był zwłaszcza $z$ Indonezja, Nigerią, Kenia, Malezją, Papuą Nową Gwinea i Sri Lanką. W pewnej części wymienionych przypadków w wyniku rozwoju systemu politycznego ukształtował się jednak HPS, zwłaszcza w Nigerii, Indonezji, Kenii i Burundi. Ponadto, pewne instytucje konsocjonalne i centrypetalne funkcjonuja lub funkcjonowały jednocześnie m.in. na Fidżi oraz w Bośni i Hercegowinie, Irlandii Północnej, Libanie i Malezji.

W swoich wcześniejszych pracach na temat HPS dokonałem poszerzenia empirycznej teorii PS, wyjaśniając genezę i istotę oraz proponując wstępne założenia koncepcji HPS. Dla realizacji tych zadań skupiłem się na badaniu przypadków Nigerii i Indonezji ${ }^{10}$. Głównym celem tego artykułu jest przedstawienie nowych, pogłębionych założeń koncepcyjnych HPS, które zdefiniowałem i usystematyzowałem na podstawie przypadków Nigerii, Indonezji, Kenii i Burundi, a także wskazanie empirycznych przykładów głównych instytucji tworzących HPS w tych państwach.

Pay? Centripetalism in Deeply Divided Societies, „Ethnopolitics” 2013, t. 12, nr 2, s. 112; D.L. Horowitz, Ethnic Power Sharing: Three Big Problems, „Journal of Democracy” 2014, t. 25, nr 2, s. 10-11; J. McGarry, B. O'Leary, Power Sharing Executives: Consociational and Centripetal Formulae and the Case of Northern Ireland, w: A. McCulloch, J. McGarry (red.), Power-Sharing: Empirical and Normative Challenges, London 2017, s. 66; B. O'Leary, Debating Consociational Politics: Normative and Explanatory Arguments, w: S. Noel (red.), From Power Sharing to Democracy: Post-Conflict Institutions in Ethnically Divided Societies, Montreal 2005, s. 3.

8 N. Bahlawan, Nowe ruchy społeczne wobec systemu politycznego $w$ Libanie po 1990 roku, Warszawa 2018, s. 9-10, 13-14, 56-67; K. Trzciński, Istota i główne modele power-sharing w warunkach wieloetniczności. Zarys problematyki, „Przegląd Politologiczny” 2016, nr 3, s. 30-31.

9 I. Dobrzeniecki, Filaryzacja - geneza, rozwój, upadek, Warszawa 2016; I. Dobrzeniecki, Filaryzacja $i$ defilaryzacja $w$ Holandii - zarys problematyki, „Studia Europejskie” 2017, nr 2, s. 163-179.

10 K. Trzciński, Ograniczanie konfliktów w Nigerii i Indonezji. Hybrydowy model power-sharing, Warszawa 2019; K. Trzciński, Hybrid Power Sharing: On How to Stabilize the Political Situation in Multi-segmental Societies, „Politeja” 2018, t. 56, nr 5, s. 86-107; K. Trzciński, Hybrid Power-Sharing in Indonesia, „Polish Political Science Yearbook” 2017, t. 46, z. 1, s. 168-185; K. Trzciński, How Theoretically Opposite Models of Interethnic Power-Sharing Can Complement Each Other and Contribute to Political Stabilization: The Case of Nigeria, „Politeja” 2016, t. 42, nr 3, s. 53-73; K. Trzcinski, The Consociational Addition to Indonesia's Centripetalism as a Tactic of the Central Authorities: The Case of Papua, „Hemispheres” 2016, t. 31, nr 4, s. 5-20. 
W artykule prezentuje poglądy sformułowane na podstawie rozumowania indukcyjnego w oparciu o studia przypadków. Studia te zostały przeprowadzone za pomoca analizy instytucjonalno-prawnej treści źródeł pierwotnych (aktów prawnych) i wtórnych (opracowań naukowych), a w znacznej części - analizy treści wywiadów częściowo ustrukturyzowanych oraz swobodnych, które przeprowadziłem w terenie.

\section{KLASYCZNE MODELE POWER-SHARING - KONSOCJONALIZM I CENTRYPETALIZM}

$\mathrm{Na}$ początku tego artykułu omawiam w sposób syntetyczny klasyczne modele power-sharing, tj. konsocjonalizm i centrypetalizm. Konsocjonalny model PS propaguje uznanie dla praw grupowych, a konkretnie dla praw segmentów, w których członkostwo opiera się na podstawach askryptywnych i kulturowych. W duchu konsocjonalizmu pewne partykularne prawa powinny przysługiwać w wielosegmentowym państwie zwłaszcza segmentom etnicznym/narodowym/ lingwistycznym lub religijnym/wyznaniowym $z$ racji posiadania przez nie i artykułowania interesów grupowych. Za najważniejsze interesy takich segmentów uznawane są: interesy ekonomiczne oraz językowe, religijne ${ }^{11}$ czy, szerzej, tożsamościowe. Instytucje konsocjonalne maja za zadanie ochronę i wzmacnianie interesów grupowych.

Koncepcja konsocjonalizmu zakłada de facto, że najlepiej dba się o własne interesy samemu. Istotę konsocjonalizmu można zatem zawrzeć w stwierdzeniu, że w warunkach społeczeństwa wielosegmentowego, zwłaszcza głęboko podzielonego, poszczególne segmenty, aby uzyskać realny udział w podejmowaniu decyzji politycznych, powinny mieć, jako sui generis grupy interesów, odrębną reprezentację we władzy państwowej. W konsekwencji, o interesy segmentów moga dbać zwłaszcza takie, najlepiej formalnie zagwarantowane, instytucje konsocjonalne, jak: wielka koalicja, tworzona zwłaszcza przez partie segmentowe lub wspólnotowe, $\mathrm{w}$ tym partie etniczne i religijne; segmentowa autonomia kulturalna, a - w miarę możliwości - również terytorialna; proporcjonalność w wyborach, rozdziale stanowisk rządowych, przy zatrudnianiu $\mathrm{w}$ urzędach $\mathrm{i}$ agendach publicznych, a nawet $\mathrm{w}$ armii, mediach i przedsiębiorstwach państwowych; oraz weto mniejszości ${ }^{12}$.

11 S.J. Kaufman, Ethnicity as a Generator of Conflict, w: K. Cordell, S. Wolff (red.), Routledge Handbook of Ethnic Conflict, London 2011, s. 91, 94-95.

12 A. Lijphart, Democracy in Plural Societies: A Comparative Exploration, New Haven CT 1980, passim; A. Lijphart, Thinking about Democracy: Power Sharing and Majority Rule in Theory and Practice, London 2008, passim. 
Model centrypetalny PS ma znacznie bardziej ograniczony związek z prawami grupowymi niż model konsocjonalny. Centrypetalizm, podobnie jak konsocjonalizm, ma zapewniać udział we władzy członkom różnych segmentów, ale nie w ramach partykularnych instytucji chroniących i wzmacniających interesy segmentów, lecz na płaszczyźnie instytucji ponadsegmentowych czy też międzysegmentowych (np. międzyetnicznych), a zatem otwartych na jednostki wywodzace się $z$ ogółu segmentów. Takie podejście przede wszystkim ma kreować wśród członków elit politycznych segmentów integrujące zachowania polityczne w poprzek podziałów segmentowych, tj. takie, które wychodza ponad interesy grupowe i depolityzuja segmentowa odrębność, osłabiając w ten sposób jej znaczenie ${ }^{13}$.

Centrypetalizm nie promuje zatem instytucjonalnego uznawania odrębności segmentów i ich interesów. Przeciwnie, ma kreować bodźce do współpracy nie tyle między „zinstytucjonalizowanymi” segmentami, ile raczej między członkami różnych segmentów, a nawet zmuszać ich do kooperacji poprzez tworzenie integrujących ram instytucjonalnych. Centrypetalizm ma równocześnie moderować politykę $\mathrm{w}$ wielosegmentowym państwie. Za główne formalne instytucje centrypetalne można uznać $^{14}$ : partie ponadregionalne, zwłaszcza międzyetniczne i, jeśli jest taka potrzeba, koalicje między nimi; decentralizację prowadzaca do dzielenia dużych segmentów na części (tak, aby zamieszkiwały one w kilku regionach administracyjnych) oraz ustanawiajaca regiony wielosegmentowe, w których członkowie regionalnych elit politycznych różnych segmentów sa „zmuszeni” do współpracy ${ }^{15}$; procedurę wyboru ponadsegmentowego (tj. popieranego przez członków różnych segmentów) prezydenta $z$ zastosowaniem tzw. wymogu terytorialnego rozłożenia głosów, tj. konieczności uzyskania odpowiednio wysokiego rozłożenia poparcia w wyborach prezydenckich na obszarze większości regionów administracyjnych (sprostanie temu wymogowi jest niezbędne do objęcia urzędu prezydenckiego, a samo zdobycie większości głosów jest niewystarczajace); stosowany w wyborach do parlamentu

${ }_{13}$ B. Reilly, Democracy and Diversity: Political Engineering in the Asia-Pacific, Oxford 2007, s. 83-91.

14 D.L. Horowitz, Ethnic Groups in Conflict, Berkeley 1985, zwłaszcza s. 601-652; S. Wolff, Consociationalism, Power Sharing, and Politics at the Center, w: R.A. Denemark (red.), The International Studies Encyclopedia, t. 2, Malden MA 2010, s. 543-545.

${ }_{15}$ Choć centrypetalne partie polityczne i centrypetalna decentralizacja zostały zidentyfikowane jeszcze w 1985 r. przez D.L. Horowitza, Ethnic Groups in Conflict..., to nadal nie sa wystarczajacco wyraźnie eksponowane w piśmiennictwie. Większość współczesnych badaczy centrypetalizmu skupia uwagę na zagadnieniach systemu wyborczego. 
(zwłaszcza izby niższej) wymóg tzw. głosowania preferencyjnego ${ }^{16}, \mathrm{np}$. $\mathrm{w}$ postaci proporcjonalnego (w okregach wielomandatowych) systemu ordynacji pojedynczego głosu przechodniego ${ }^{17}$, albo - większościowego (w okregach jednomandatowych) systemu głosu alternatywnego ${ }^{18}$ lub innych rozwiazań promujących łączenie przez różne segmenty głosów wyborczych dzięki stworzeniu wspólnej puli kandydatów na liście wyborczej (ang. vote-pooling), co ma prowadzić do głosowania w poprzek podziałów segmentowych ${ }^{19}$.

Instytucjom różnych modeli PS towarzyszą polityki integracyjne (w przypadku centrypetalizmu) lub chroniace interesy (wybranych) segmentów (w przypadku konsocjonalizmu). Przykładami polityk centrypetalnych są: wprowadzenie języka narodowego oraz mieszanie członków różnych grup etnicznych i wspólnot religijnych w Indonezji, dzięki sponsorowanej do niedawna przez rząd tzw. transmigracji, tj. przesiedleniom ludności z obszarów przeludnionych na tereny słabiej zaludnione $^{20}$. Z kolei przykładem polityki konsocjonalnej może być np. akcja afirmatywna, dotyczaca np. edukacji i zatrudnienia, prowadzona zwłaszcza wobec Malajów w Malezji ${ }^{21}$.

\section{HYBRYDOWE POWER-SHARING - INSTYTUCJE}

Hybrydowe power-sharing jest koncepcyjnie i instytucjonalnie odmienne od innych empirycznych modeli PS, konsocjonalizmu i centrypetalizmu. Model ten opiera się na mieszanych założeniach koncepcyjnych: własnych, centrypetalnych i konsocjonalnych. W ramach HPS łaczone sa instytucje centrypetalne i konsocjonalne, a także

16 Głosowanie preferencyjne, dzięki dokonywanemu przez wyborców rankingowi kandydatów, pozwala na wskazanie preferencji dotyczących kandydatów wywodzących się $\mathrm{z}$ różnych partii. Głosowanie to w przypadku centrypetalizmu ma za zadanie zmniejszenie możliwości zdobycia mandatów parlamentarnych przez polityków mało powściagliwych w poglądach i działaniach odnoszacych się zwłaszcza do relacji międzysegmentowych.

17 B. Reilly, Democracy in Divided Societies: Electoral Engineering for Conflict Management, Cambridge 2001. s. 17-18, 31-33.

18 D.L. Horowitz, Domesticating Foreign Ideas in the Adoption of New Institutions: Evidence from Fiji and Indonesia, w: J.D. Montgomery, N. Glazer (red.), Sovereignty under Challenge: How Governments Respond, New Brunswick NJ 2002, s. 207-209; J. Coakley, J. Fraenkel, The Ethnic Implications of Preferential Voting, "Government and Opposition” 2017, t. 52, z. 4, s. 671-697; A. Lijphart, Constitutional Design for Divided Societies, „Journal of Democracy" 2004, t. 15, z. 2, s. 96-109.

19 B. Reilly, Cross-Ethnic Voting: An Index of Centripetal Electoral Systems, „Government and Opposition" 2020, s. 1-20; M. Bogaards, Consociationalism and Centripetalism: Friends or Foes? „Swiss Political Science Review” 2019, t. 25, z. 4, s. 519-537.

${ }^{20}$ K. Trzciński, Ograniczanie konfliktów $w$ Nigerii $i$ Indonezji..., passim.

21 D.L. Horowitz, Ethnic Groups in Conflict..., s. 653-680. A Jelonek, Dylematy konsocjonalizmu. Przypadek Malezji, Warszawa 2004, passim. 
hybrydowe. HPS został wdrożony w kilku państwach wielosegmentowych, w tym w Nigerii, Indonezji, Burundi i Kenii.

Założenia koncepcyjne $z$ odwołaniami do konkretnych przypadków i (lub) instytucji HPS prezentuję w dalszej części artykułu. W tej części przedstawiam podstawowe instytucje HPS funkcjonujacce we wskazanych państwach ${ }^{22}$.

I tak, w Nigerii istnieja następujące podstawowe instytucje o charakterze centrypetalnym ${ }^{23}:$ 1) ponadregionalne, międzyetniczne i międzyreligijne partie polityczne (przy jednoczesnym całkowitym zakazie tworzenia partii etnicznych i religijnych), których charakter przyczynia się do tworzenia wieloetnicznego i wieloreligijnego składu parlamentu; 2) procedura wyboru „ponadsegmentowego" prezydenta oparta na wymogu terytorialnego rozłożenia głosów (w pierwszej lub, ewentualnie, drugiej turze wybory prezydenckie może wygrać jedynie ten kandydat, który zdobył zwykłą większość głosów w całym państwie oraz nie mniej niż 25 proc. głosów w każdym $z$ co najmniej 2/3 ogółu głównych jednostek terytorialnych ${ }^{24}$; łacznie w Nigerii jest 37 takich jednostek: 36 stanów i Federalne Terytorium Stołeczne); 3) struktura terytorialna składająca się $z$ wielosegmentowych stanów (wieloetnicznych, a zwykle również i wieloreligijnych), która „rozbija” główne grupy etniczne (Hausa-Fulanich na 9 stanów, Jorubów na 7 i Igbów na 5$)^{25}$ oraz grupuje niektóre mniejsze segmenty w odrębnych stanach, „uwalniając” je spod władzy dużych grup.

Do głównych instytucji konsocjonalnych w Nigerii należą ${ }^{26}:$ 1) nieformalna rotacja prezydentury między muzułmanami i chrześcijanami (dokładnie: między zdominowana przez muzułmanów Północa a Południem zamieszkałym głównie przez chrześcijan), która zapewnia wymienną reprezentację na urzędzie prezydenta wyznawców obu

${ }^{22} \mathrm{~W}$ artykule tym nie skupiam się na instytucjach PS funkcjonujących na lokalnym poziomie władzy.

${ }^{23}$ Konstytucja Republiki Federalnej Nigerii z 29 maja 1999 r., w: World International Property Organization (http://www.wipo.int/wipolex/en/text.jsp?file_id=179202); K. Trzciński, How Theoretically Opposite Models of Interethnic Power-Sharing..., s. 61-66.

${ }^{24}$ K. Trzciński, The Centripetal Spatial Vote Distribution Requirement in Presidential Elections: Cases of Nigeria and Indonesia, „Acta Asiatica Varsoviensia” 2017, t. 30, z. 1, s. $98-107$.

25 R.T. Suberu, Federalism and the Management of Ethnic Conflict: The Nigerian Experience, w: D. Turton (red.), Ethnic Federalism: The Ethiopian Experience in Comparative Perspective, Oxford 2006, s. 73-74.

26 S.A. Rustad, Power-Sharing and Conflict in Nigeria: Power-Sharing Agreements, Negotiations and Peace Processes, International Peace Research Institute in Oslo, „CSCW Papers”, Oslo 2008, s. 19-22; K. Trzciński, How Theoretically Opposite Models of Interethnic Power-Sharing..., s. 66-69; R.T. Suberu, Federalism and the Management of Ethnic Conflict..., s. 75-76. 
głównych religii; 2) nieformalny wymóg, zgodnie $z$ którym wiceprezydentura przypada członkowi innej wspólnoty religijnej i grupy etnicznej niż te, $z$ których wywodzi się prezydent (obie instytucje razem zapewniają jednoczesną reprezentację $\mathrm{w}$ najwyższym organie egzekutywy wyznawców dwóch głównych religii i członków różnych grup etnicznych); 3) prawo szariatu (jako wyraz autonomii kulturowej) w stanach, w których przeważają muzułmanie; 4) wymóg zwrotu przez rząd federalny do kilku południowych stanów Nigerii (położonych w Delcie Nigru) części dochodów czerpanych $z$ wydobywania w nich surowców energetycznych.

W Nigerii wykształcona została również instytucja hybrydowa $\mathrm{w}$ postaci specyficznej procedury ustanawiania wielosegmentowego składu rządu ${ }^{27}$.

W Indonezji funkcjonuja następujące podstawowe instytucje centrypetalne ${ }^{28}:$ 1) ponadregionalne, międzyetniczne partie polityczne, których charakter przyczynia się do tworzenia wieloetnicznego składu parlamentu (i w mniejszym stopniu rzadu); 2) procedura wyboru „ponadetnicznego" prezydenta oparta na wymogu terytorialnego rozłożenia głosów (w zgodzie $z$ nim, aby w pierwszej turze wygrać wybory prezydenckie, należy zdobyć bezwzględna większość głosów w całym państwie i jednocześnie co najmniej 20 proc. głosów w więcej niż połowie $z 34$ prowincji) ${ }^{29}$; 3) struktura terytorialna składająca się $\mathrm{w}$ przeważającym stopniu $z$ wieloetnicznych prowincji i zarazem dzieląca główna grupę etniczna, Jawajczyków (stanowiących ponad 40 proc. populacji Indonezji), na mieszkańców aż 6 prowincji na wyspie Jawa.

Do podstawowych instytucji konsocjonalnych w Indonezji nale$\dot{z} \mathrm{a}^{30}:$ 1) specjalna autonomia dla prowincji Aceh, Papua i Papua Zachodnia $^{31}$; wśród kluczowych rozwiązań autonomicznych sa: w Aceh prawo szariatu, które nie obowiązuje $\mathrm{w}$ innych częściach Indonezji ${ }^{32}$; w prowincjach papuaskich wymóg rodzimego pochodzenia guberna-

${ }^{27}$ Instytucja ta jest omówiona w dalszej części artykułu.

28 Konstytucja Republiki Indonezji z 18 sierpnia 1945 r. (z późniejszymi zmianami), w: World Intellectual Property Organization (http://www.wipo.int/edocs/lexdocs/laws/en/ id/id061en.pdf); K. Trzciński, Hybrid Power-Sharing in Indonesia..., s. 174-177; B. Reilly, Cross-Ethnic Voting..., s. 6-8.

${ }^{29}$ K. Trzciński, The Centripetal Spatial Vote Distribution Requirement..., s. 101-107.

30 K. Trzciński, Hybrid Power-Sharing in Indonesia..., s. 177-181.

$31 \mathrm{~W}$ przypadku prowincji Papua i Papua Zachodnia prawnie zagwarantowana specjalna autonomia została implementowana tylko częściowo.

32 Ustawa Republiki Indonezji $n r 11$ z 2006 r. dotyczaca rząów w Aceh, w: Kementerian Luar Negeri (http://pih.kemlu.go.id/files/UU\%2011-\%202006.pdf). 
torów i ich zastępców ${ }^{33}$; partie etniczne w Aceh $^{34}$; gwarancja zachowania przez prowincje Aceh, Papua i Papua Zachodnia zasadniczej części wpływów, jakie generuje eksploatacja ich bogactw naturalnych ${ }^{35}$;

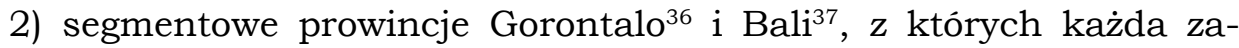
mieszkała jest w zdecydowanej większości przez członków jednej grupy etnicznej i zarazem jednej wspólnoty religijnej; 3) proporcjonalny system wyborczy do izby niższej parlamentu ${ }^{38}$.

W Indonezji wdrożona została również instytucja hybrydowa w postaci ponadregionalnych partii religijnych ${ }^{39}$.

W Burundi, zamieszkałym niemal w całości przez członków dwóch grup etnicznych (Hutu i Tutsi), istnieja następujące podstawowe instytucje o charakterze konsocjonalnym ${ }^{40}: 1$ ) międzyetniczny rząd składający się z co najwyżej 60 proc. ministrów Hutu i co najwyżej 40 proc. ministrów Tutsi ${ }^{41}$; 2) proporcjonalność oparta na kwotach etnicznych w dwóch izbach parlamentu Burundi i tzw. mechanizmie kooptacji ${ }^{42}$, który działa $\mathrm{w}$ przypadku problemów $z$ osiagnięciem konstytucyjnie zakładanych proporcji (w izbie niższej parlamentu, Zgromadzeniu Narodowym, proporcje udziału Hutu i Tutsi wynosza $60 \%$ do $40 \%$, a w izbie wyższej, Senacie, funkcjonuje równa reprezentacja tych segmentów ${ }^{43}$ ); 3) wymóg tzw. „etnicznej równowagi” Hutu i Tutsi w armii

33 Ustawa Republiki Indonezji $n r 21$ z 2001 r. o specjalnej autonomii dla Prowincji Papua, w: Human Rights and Peace for Papua (http://www.humanrightspapua.org/resources/nlaw/82-otsus).

${ }^{34}$ K. Trzciński, Wygrać, aby przegrać? Rzecz o genezie, istocie i politycznych skutkach specjalnej autonomii prowincji Aceh $w$ Indonezji, „Studia Politologiczne” 2018, t. 50, s. 248$-253$.

${ }^{35}$ K. Trzciński, The Consociational Addition to Indonesia's Centripetalism..., s. 16.

36 W 2000 r. z prowincji Celebes Północny, w której większość stanowią chrześcijanie, wydzielono prowincję Gorontalo, w której zdecydowana większość mają muzułmanie, głównie członkowie jednej grupy etnicznej Gorontalo. Zdominowane przez muzułmanów władze Indonezji, tworzac nowa prowincję, de facto ukróciły polityczną i ekonomiczną dominację chrześcijan (głównie $z$ grupy etnicznej Minahasa) w prowincji Celebes Północny nad muzułmanami zamieszkującymi głównie obszar Gorontalo. Taki wniosek płynie $z$ moich rozmów z badaczami polityki indonezyjskiej odbytych w 2017 r. w Indonezji. Por. E. Kimura, Marginality and Opportunity in the Periphery: The Emergence of Gorontalo Province in North Sulawesi, „Indonesia” 2007, nr 84, s. 72, 77, 85-92, 94-95.

37 Specyfika funkcjonowania tej segmentowej prowincji, zamieszkałej w zdecydowanej większości przez będących hinduistami Balijczyków, związana jest $z$ istnieniem tradycji odrębności administracyjnej oraz granic naturalnych w ramach jednej wyspy.

38 System ten jest mało istotny w sytuacji braku na poziomie całego państwa partii etnicznych i innych partii religijnych niż reprezentujące muzułmańską większość.

39 K. Trzciński, Ograniczanie konfliktów w Nigerii i Indonezji..., s. 104-105.

40 Konstytucja Burundi z 21 maja 2018 r., w: Constitute: Comparative Constitutions Project (https://www.constituteproject.org/constitution/Burundi_2018.pdf?lang=en).

41 Ibidem, art. 128.

42 Ibidem, art. 169 i 185.

${ }^{43}$ Ponadto $\mathrm{w}$ obu izbach parlamentu po trzy miejsca sa zarezerwowane dla reprezentantów grupy etnicznej Twa. Ibidem, art. 169 i 185. 
i innych służbach odpowiedzialnych za bezpieczeństwo oraz towarzyszący mu wymóg, zgodnie $z$ którym minister obrony musi pochodzić $z$ innej grupy etnicznej niż minister odpowiedzialny za policję ${ }^{44}$; 4) tzw. wzajemne weto odnoszące się głównie do tzw. ustaw organicznych ${ }^{45}$ (tj. zasada większości kwalifikowanej w obu izbach parlamentu, zgodnie $z$ która decyzje dotyczące ustaw organicznych podejmowane sa większością dwóch trzecich głosów tych, którzy uczestniczą w głosowaniu, a zatem muszą być poparte zarówno przez parlamentarzystów Hutu, jak i Tutsi) ${ }^{46}$; 5) wymóg, aby stanowiska prezydenta i wiceprezydenta były obsadzone przedstawicielami różnych grup etnicznych ${ }^{47}$; w praktyce urzad prezydenta Burundi przypada członkowi grupy etnicznej Hutu (mającej ok. 85 proc. udział w populacji), a wiceprezydenta - członkowi grupy etnicznej Tutsi (liczącej ok. 14 proc. populacji).

Burundyjska procedurę wyboru posłów oparta na międzyetnicznych zamkniętych listach wyborczych i proporcjonalnym systemie wyborczym ( $z$ listami partyjnymi) należy uznać za instytucję hybrydowa ${ }^{48}$.

Instytucją centrypetalną w Burundi sa międzyetniczne partie polityczne ${ }^{49}$.

W Kenii istnieja następujące podstawowe instytucje centrypetal$\left.n e^{50}: 1\right)$ ponadregionalne i międzysegmentowe (międzyetniczne i międzyreligijne) partie polityczne (przy jednoczesnym całkowitym zakazie tworzenia partii etnicznych i religijnych) oraz 2) procedura wyboru „ponadetnicznego” prezydenta na podstawie wymogu terytorialnego rozłożenia głosów (w pierwszej turze wyborów prezydentem Kenii może zostać wybrany jedynie ten kandydat, który zdobył bezwzględna większość głosów w całym państwie oraz co najmniej 25 proc. głosów $\mathrm{w}$ więcej niż połowie z $47 \mathrm{hrabstw})^{51}$.

44 Ibidem, art. 192 (5), 261, 264

45 Są to ustawy dotyczące bardzo ważnych zagadnień zwłaszcza natury ustrojowej. Z punktu widzenia znaczenia, ustawy takie są plasowane między konstytucją a zwykłymi ustawami. Instytucja ustawy organicznej nie istnieje w prawie polskim.

46 Konstytucja Burundi z 21 maja 2018 r. ..., art. 180, 191, 196, 202; A. McCulloch, S. Vandeginste, Veto Power and Power-Sharing: Insights from Burundi (2000-2018), „Democratization" 2019, t. 26, z. 7, s. 1176-1193.

47 Konstytucja Burundiz 21 maja 2018 r. ..., art. 124.

48 Ibidem, art. 173.

49 Ibidem, art. 78.

50 Konstytucja Kenii z 27 sierpnia 2010 r., w: World Intellectual Property Organization (https://www.wipo.int/edocs/lexdocs/laws/en/ke/ke019en.pdf).

51 I. Dobrzeniecki, Wymóg terytorialnego rozłożenia głosów w wyborach prezydenckich. Przypadek Kenii, „Studia Polityczne” 2017, t. 45, nr 4, s. 171-191. K. Trzciński, Wymóg uzyskania terytorialnego rozłożenia głosów (poparcia) $w$ wyborach prezydenckich, „Athenaeum” 2016 , t. 49, s. 120-122, 128-133. 
Obecnie w Kenii funkcjonuje również instytucja konsocjonalna w postaci autonomii kulturowej dla segmentów etnicznych i religijnych $^{52}$ (zawierająca zwłaszcza: ochronę i promocję języków etnicznych; wolność działania różnego rodzaju stowarzyszeń i organizacji etnicznych; a także autonomiczne muzułmańskie sądownictwo, kadhi - ok. 11 proc. Kenijczyków jest muzułmanami) ${ }^{53}$. Bardzo istotna konsocjonalna instytucja istniała w Kenii w latach 2008-2013. Był to gabinet wielkiej koalicji (tzw. rząd jedności narodowej), w którym zasiadali głównie członkowie grup etnicznych: Kikuju, Luja, Luo, Kalendżin i Kamba, których udział w populacji całego państwa wynosi w każdym przypadku ponad 10 proc. ${ }^{54}$

W Kenii można również wyróżnić dwie instytucje hybrydowe - specyficzną strukturę terytorialna ${ }^{55}$ i wymóg wielosegmentowego charakteru tzw. narodowej egzekutywy ${ }^{56}$.

\section{ZAŁOŻENIA KONCEPCYJNE HYBRYDOWEGO POWER-SHARING}

W tej części artykułu prezentuję założenia koncepcyjne HPS, posiłkując się przykładami konkretnych przypadków i (lub) instytucji HPS.

Charakterystykę założeń koncepcyjnych HPS rozpoczynam od przedstawienia założenia o charakterze „porządkujacym”, które stanowi, że HPS należy postrzegać wielopoziomowo, tj. jako model ogólny i jego warianty wyróżniane w zależności od specyfiki. Ponieważ teoria HPS ma różne poziomy ogólności i szczegółowości można w jej ramach zaproponować pewną systematyzację. I tak, po pierwsze, należy wyróżnić HPS jako model ogólny, jeden z trzech głównych empirycznych modeli PS, obok konsocjonalizmu i centrypetalizmu. Po drugie, można wyróżnić dwa warianty szczegółowe HPS: centrypetalno-konsocjonalny (jak np. w Nigerii, Indonezji i Kenii) oraz konsocjonalno-centrypetalny (za przykład może tu posłużyć przypadek

52 Konstytucja Kenii z 27 sierpnia 2010 r. ..., art. 7 (3), 44, 56.

${ }_{53}$ Autonomia kulturowa, mimo że jest zaliczana w literaturze przedmiotu do instytucji konsocjonalnych, nie ma większego znaczenia $z$ punktu widzenia dzielenia się władzą przez segmenty albo między władzą centralną a segmentami.

54 N. Cheeseman, C. Murray, Power-Sharing in Kenya: Between the Devil and the Deep Blue Sea, w: A. McCulloch, J. McGarry (red.), Power-Sharing..., s. 36-62.

55 Por. C.M. Bosire, Kenya's Ethno-Politics and the Implementation of Devolution under the Constitution of Kenya 2010, w: Swedish International Centre for Local Democracy, Workshop on Devolution and Local Development in Kenya (26 June 2014, Nairobi) - Proceedings No. 2, Malmö 2015, s. 15-16.

56 Konstytucja Kenii z 27 sierpnia 2010 r. ..., art. 130. 
Burundi). Pierwszy człon nazwy wariantu wskazuje na przewagę znaczeniowa instytucji centrypetalnych lub konsocjonalnych i zarazem dominujacy charakter centrypetalizmu lub konsocjonalizm w HPS. Można również założyć istnienie w jakimś przypadku HPS przewagi instytucji hybrydowych i w konsekwencji innych wariantów HPS niż centrypetalno-konsocjonalny i konsocjonalno-centrypetalny. Po trzecie, ponieważ specyficznych przykładów łączenia instytucji jednego modelu $z$ jakimiś wybranymi instytucjami innego modelu może być bardzo wiele, dodatkowo należy wyróżnić różne oryginalne warianty HPS, np. indonezyjski, nigeryjski, burundyjski. Można je określać mianem „narodowych” wariantów HPS, bowiem każdorazowo sa one unikalne dla konkretnego państwa. Pierwszy i trzeci z wyróżnionych poziomów odnoszą się również do innych modeli PS.

Egzemplifikacji wielopoziomowego rozumienia HPS niech posłuży przykład nigeryjskiego PS. Można go nazwać systemem centrypetalno-konsocjonalnym, ponieważ dominującą rolę pełnią w nim instytucje centrypetalizmu. Natomiast biorąc pod uwagę specyfikę dodania wybranych instytucji konsocjonalnych do dominujących instytucji centrypetalnych, należy go po prostu nazywać modelem nigeryjskim. Reasumując, system polityczny typu power-sharing istniejaccy w Nigerii jest centrypetalno-konsocjonalnym, nigeryjskim HPS. $Z$ kolei np. system polityczny funkcjonujacy np. w Burundi jest konsocjonalno-centrypetalnym, burundyjskim HPS.

W dalszej części artykułu wykładam siedem dotychczas zidentyfikowanych i usystematyzowanych założeń koncepcyjnych HPS o charakterze „ideowym":

- W HPS lączone są instytucje różnych modeli PS. Z HPS mamy do czynienia wówczas, gdy w tym samym wielosegmentowym państwie (np. w Nigerii, Indonezji, Burundi, Kenii) jednocześnie funkcjonuja instytucje, które można określić mianem heterogenicznych, gdyż pochodza $z$ modeli PS, które mają inne założenia koncepcyjne. HPS cechuje zatem swoisty kompromis instytucjonalny.

$\mathrm{Na}$ pierwszy rzut oka centrypetalizm i konsocjonalizm sa trudne do pogodzenia ze względu na różne założenia koncepcyjne. Nie znaczy to jednak, że instytucje jednego i drugiego typu nie moga współistnieć $\mathrm{w}$ jednym wielosegmentowym państwie. Używając analogii, sytuacja ta przypomina tworzenie rządu koalicyjnego przez partie polityczne majace inne podstawy ideologiczne i programy polityczne, np. przez partie lewicowe i prawicowe. 
HPS może być kształtowany głównie poprzez dodanie do jednego modelu PS, centrypetalizmu lub konsocjonalizmu, pewnych instytucji innego modelu PS. HPS może być również kształtowany od podstaw, już na samym początku tworzenia systemu politycznego typu PS w jakimś wielosegmentowym państwie. Oznacza to, że instytucje jednego modelu PS nie musza być dodawane do innego modelu PS dopiero wówczas, gdy zajdzie taka potrzeba.

- HPS zwykle jest kształtowany wówczas, gdy sam centrypetalizm lub konsocjonalizm nie jest wystarczający dla uzyskania i (lub) trwania stanu stabilności politycznej. Stabilność polityczna w warunkach państwa wielosegmentowego jest tu rozumiana w najprostszy sposób jako ustanowienie pokoju poprzez ograniczenie konfliktów w relacjach między segmentami i (lub) między segmentami a władzą państwowa.

Zarówno centrypetalizm, jak i konsocjonalizm funkcjonujące samodzielnie nie zawsze przyczyniaja się do uzyskania i (lub) trwania stabilności politycznej w państwie wielosegmentowym. Niekiedy skuteczniejsze dla osiagnnięcia tego celu może być łączenie instytucji różnych modeli PS. Jest tak np. wówczas, gdy elity polityczne jakiegoś segmentu lub segmentów nie sa zadowolone $z$ efektów funkcjonowania instytucji danego modelu PS, gdyż np. uważaja, że instytucje te w niewystarczajacy sposób gwarantują realizację interesów ich segmentów.

Zarówno konsocjonalizm, jak i centrypetalizm mają bowiem wady. I tak, konsocjonalizm może przede wszystkim podnosić świadomość członków segmentów w kwestii korzyści, jakie daje segmentowa przynależność w warunkach funkcjonowania instytucji konsocjonalnych, i w konsekwencji wzmacniać tożsamości segmentowe oraz polityzować np. etniczność lub religię. Centrypetalizm zaś może w pierwszej kolejności chronić interesy głównego segmentu (jak w Indonezji) lub głównych segmentów (jak w Nigerii). Centrypetalizm może zatem służyć głównie dużym segmentom, które w ograniczony sposób dokooptowuja do udziału we władzy chętnych do współpracy członków elit politycznych mniejszych segmentów.

Ponieważ, jak uczy doświadczenie, systemy polityczne typu PS bywają nietrwałe, być może dzięki dodaniu do instytucji centrypetalnych lub konsocjonalnych instytucji innego modelu PS możliwe jest również uzyskanie efektu w postaci ogólnego ugruntowania systemu politycznego typu PS i instytucji, które wywodzą się z pierwotnie zastosowanego modelu PS. Innymi słowy, dodanie np. pewnych instytu- 
cji konsocjonalnych może stabilizować instytucje systemu politycznego o charakterze stricte centrypetalnym.

Można założyć, że - w warunkach stabilności politycznej - HPS, tak jak i centrypetalne lub konsocjonalne PS, będzie istniało tak długo, jak będzie potrzebne, w tym np. dopóki będzie przynosić korzyści przede wszystkim ważnym aktorom polityki w państwie wielosegmentowym, w tym elitom segmentów istotnych pod względem liczebnym i (lub) siłowym.

- W HPS łączenie instytucji różnych modeli PS służy uzyskaniu stabilności politycznej wówczas, gdy instytucje te nie stoja w sprzeczności. Przy łączeniu w HPS instytucji różnych modeli PS jedno kryterium ma zasadnicze znaczenie - instytucje odmiennych modeli PS nie moga być przeciwskuteczne. Brak harmonii między instytucjami różnych modeli PS może bowiem dać efekt przeciwny od zakładanego - zamiast uzyskania stabilności politycznej może prowadzić do destabilizacji sytuacji politycznej w wielosegmentowym państwie.

Dobrym przykładem takiej sytuacji jest historyczny już kazus Fidżi ${ }^{57}$, które pod rząami konstytucji z 1997 roku nie miało ani pełnego systemu konsocjonalnego, ani rozbudowanego systemu centrypetalnego, a jedynie wybrane instytucje obu modeli, które jednak wzajemnie się wykluczały. Konkretnie chodzi tu o centrypetalna instytucje głosowania alternatywnego, której rola w systemie politycznym została zaburzona przez konsocjonalna instytucję gwarancji proporcjonalnego do liczby posłów udziału w rządzie de facto każdej partii politycznej, która zdobyłaby w wyborach 10 proc. lub więcej mandatów parlamentarnych. Konsekwencjami wprowadzenia do systemu politycznego Fidżi tych instytucji była destabilizacja sytuacji politycznej i zlikwidowanie PS.

- W HPS znaczenie instytucji centrypetalizmu i konsocjonalizmu ma charakter asymetryczny, co oznacza, że jeden $z$ tych modeli ma charakter dominujący. Jak pokazuje doświadczenie Nigerii, Indonezji, Kenii i Burundi, instytucje oparte na założeniach koncepcyjnych jednego modelu PS, centrypetalizmu lub konsocjonalizmu, każdorazowo mają w HPS pozycję dominującą dzięki pełnionej

57 Konstytucja Fidżi z 25 lipca 1997 r., art. 54 (1) i art. 99 (5), w: World International Property Organization (https://www.wipo.int/edocs/lexdocs/laws/en/fj/fj011en. pdf). Zob. też art. 99 (4) - (6); J. Fraenkel, Mandatory Power-Sharing in Coup-Prone Fiji, w: A. McCulloch, J. McGarry (red.), Power-Sharing..., s. 103-123. D.L. Horowitz, Domesticating Foreign Ideas..., s. 197-220. Dziękuję D.L. Horowitzowi za przypomnienie mi przypadku kolidujących ze sobą instytucji PS na Fidżi. 
roli w systemie politycznym. Udział instytucji obu modeli w HPS ma zatem charakter asymetryczny.

Pozycja dominująca oznacza przewage znaczeniowa związana $z$ rolą instytucji któregoś $z$ modeli PS $w$ systemie politycznym danego państwa, w tym $z$ zasięgiem ich oddziaływania (np. instytucje ponadregionalne sa zwykle istotniejsze od istniejacych w jakimś regionie). W przypadku nigeryjskim pozycja dominujacca centrypetalizmu wiąże się również $z$ tym, że jego instytucje mają charakter formalny, a zatem sa umocowane prawnie, co zwykle nadaje instytucjom PS większą trwałość. $Z$ kolei część instytucji konsocjonalnych w Nigerii ma naturę nieformalna i można je łatwiej zlikwidować (co w pewnych przypadkach może być jednak korzystne).

Pozycja dominująca nie jest związana $z$ samą liczba instytucji danego modelu PS. Można sobie wyobrazić np. przypadek HPS, w którym dominująca rolę pełnią instytucje centrypetalne, ale instytucji konsocjonalnych jest więcej.

HPS musi mieć naturę asymetryczną. Trudno wyobrazić sobie sytuację, w której w danym państwie funkcjonują wszystkie lub większość głównych instytucji obu modeli PS i w rezultacie HPS ma charakter zrównoważony zamiast asymetrycznego. W takim stanie rzeczy główne instytucje obu modeli PS stałyby bowiem w sprzeczności i były przeciwskuteczne. Natomiast nie można wykluczyć, że w przyszłości w HPS jakiegoś wielosegmentowego państwa znaczenie treści centrypetalnych i konsocjonalnych, być może dzięki ich (częściowemu) łączeniu w instytucje hybrydowe, będzie bardziej zrównoważone niż ma to miejsce w obecnie istniejacych kazusach HPS.

- W HPS moga zostać wykształcone "wlasne” instytucje hybrydowe. Choć HPS bazuje na „czystych” instytucjach centrypetalizmu i konsocjonalizmu, może być rozwijany również poprzez dodawanie „własnych” instytucji. W HPS moga (ale nie musza) być tworzone nowe instytucje, w których zazębiaja się elementy charakterystyczne dla centrypetalizmu oraz typowe dla konsocjonalizmu. Nazywam je instytucjami hybrydowymi.

Instytucję tego typu przedstawiam na przykładzie nigeryjskim ${ }^{58}$. Za instytucję hybrydowa można w Nigerii uznać procedurę ustanawiania wielosegmentowego składu rządu, a konkretnie zespół reguł regulujacych wielosegmentowy skład rady ministrów. W państwie tym rada ministrów tworzona jest przez partię (lub koalicję partii), która

58 Oprócz Nigerii instytucje hybrydowe funkcjonują również w Indonezji, Kenii i Burundi. Ich specyfikę omówię w odrębnej pracy. 
ma charakter ponadregionalny, międzyetniczny i międzyreligijny, bo tylko takie partie o charakterze centrypetalnym moga funkcjonować. $Z$ drugiej jednak strony, w Nigerii istnieje konsocjonalna w swym charakterze, bo parytetowa, tzw. reguła federalnego charakteru ${ }^{59}$, która m.in. nakazuje konstytuowanie wielosegmentowej rady ministrów, tzn. składającej się $z$ mieszkańców różnych stanów, którzy są członkami różnych segmentów. Konkretnie, ta umocowana konstytucyjnie reguła nakazuje, by w skład gabinetu rady ministrów wchodził co najmniej jeden minister z każdego z 36 stanów, który jest jego rodzimym mieszkańcem. Obowiąujący od 1996 roku podział Nigerii na 36 stanów doprowadził do sytuacji, w której trzy główne grupy etniczne (Hausa-Fulani, Jorubowie i Igbowie) stanowią większość w 21 stanach, a 15 stanów jest rządzonych przez mniejsze grupy etniczne. Poprzez połączenie reguły federalnego charakteru $z$ realiami struktury terytorialnej ustalono zatem formalny parytet regionalnej reprezentacji $\mathrm{w}$ rządzie $\mathrm{i}$ zarazem wynikający $\mathrm{z}$ niego pośrednio parytet udziału $\mathrm{w}$ rządzie głównych grup etnicznych ${ }^{60}$ i religijnych ${ }^{61}$, de facto w postaci zarezerwowanych dla ich członków miejsc, a także dopuszczono do udziału w rządzeniu członków mniejszych grup etnicznych. W przypadku stanów, w których nie dominuje żadna $z$ trzech głównych nigeryjskich grup etnicznych, istnieje przy tym większe prawdopodobieństwo rotacji stanowisk w rządzie między mniejszymi grupami etnicznymi, np. w następujących po sobie gabinetach, niż w przypadku, gdy w danym stanie większość mieszkańców stanowia członkowie głównych grup etnicznych ${ }^{62}$.

W nigeryjskiej rzeczywistości politycznej centrypetalne partie delegują do rządu swych członków, którzy wywodza się z różnych grup etnicznych i wspólnot religijnych, głównie dlatego że tak nakazuje konsocjonalna reguła federalnego charakteru, a nie dlatego, że wynika to $z$ samej natury partii centrypetalnych. Procedura wyłaniania wielosegmentowego składu rady ministrów łączy zatem elementy dwóch modeli PS. Instytucja ta musi mieć naturę hybrydowa najprawdopodobniej dlatego, że sama instytucja centrypetalnych partii politycznych nie

59 Konstytucja Republiki Federalnej Nigerii z 29 maja 1999 r. ..., art. 14 (3) i 318 (1).

$60 \mathrm{Z}$ moich rozmów $\mathrm{Z}$ badaczami polityki nigeryjskiej odbytych w $2018 \mathrm{r}$. w Nigerii wynika, że sytuacja, w której członek grupy etnicznej majacej w danym stanie charakter dominujący zostaje ministrem - „reprezentantem” tego stanu w rzadzie federalnym - jest typowa.

61 Zwykle bowiem większość członków konkretnych grup etnicznych wyznaje chrześcijaństwo lub islam. I tak, niemal wszyscy Hausa-Fulani są muzułmanami, a większość Jorubów i zdecydowana większość Igbów jest chrześcijanami.

62 Takie wnioski płyna $z$ moich rozmów $z$ badaczami polityki nigeryjskiej. 
gwarantuje w pełni należytej reprezentacji w rządzie zwłaszcza mniejszych grup etnicznych.

- W HPS następuje uelastycznianie założeń koncepcyjnych dominujacego modelu PS. U podstaw każdego narodowego wariantu HPS leżą trzy grupy założeń koncepcyjnych - założenia własne HPS, założenia dominującego modelu PS i założenia niedominującego modelu PS. W HPS zwłaszcza założenia dominującego modelu PS muszą stać się bardziej elastyczne, a zatem mniej pryncypialne, niż ma to miejsce w przypadku „czystego" centrypetalizmu lub konsocjonalizmu, bowiem dodane instytucje innego modelu PS koresponduja $z$ jego własnymi założeniami koncepcyjnymi. Samo dodanie do jednego modelu PS instytucji innego modelu PS konceptualnie zmienia i „ogranicza” zwłaszcza ten pierwszy. W praktyce oznacza to, że aktorzy polityczni (zwłaszcza władza centralna) państwa wielosegmentowego staja się wraz $z$ rozwojem HPS mniej dogmatyczni w kwestiach ideologicznych, tzn. nie moga być ani nazbyt integracyjni, ani zbyt otwarci na uznawanie i ochronę interesów segmentowych. HPS cechuje zatem swoisty kompromis koncepcyjny. I tak np. Kenia, która, z jednej strony, ma centrypetalne partie polityczne, $z$ drugiej, dopuszcza polityki akcji afirmatywnej dla wybranych segmentów ${ }^{63}$.

Kompromis koncepcyjny musi być tym większy, im więcej instytucji modelu niedominujacego jest dodawanych do modelu dominującego. Zapewne największy kompromis koncepcyjny musi zaistnieć wówczas, gdy HPS jest kształtowany przez konstytucjonalistów i polityków od podstaw, a zatem już na samym początku tworzenia systemu politycznego typu PS w jakimś wielosegmentowym państwie a nie w sytuacji, w której do już istniejącego modelu PS dodawane sa instytucje innego modelu PS.

- HPS jest elastycznym systemem politycznym pod względem instytucjonalnym, ale tylko do pewnego stopnia. Teoria HPS nie ustala „z góry”, które instytucje niedominującego modelu PS i w jakiej liczbie mają być dodane do dominującego modelu PS, a także czy maja to być instytucje wyłącznie formalne, czy również nieformalne. Przeciwnie, np. do centrypetalnego PS moga zostać dodane takie instytucje konsocjonalne, które sa po prostu potrzebne. W każdym przypadku konkretna potrzeba łączenia instytucji różnych modeli PS może być inna, zostać wyartykułowana przez elity jednego lub więcej

63 Konstytucja Kenii z 27 sierpnia 2010 r. ..., art. 56. 
segmentów i odnosić się do różnych płaszczyzn dzielenia się władzą. Najważniejsze jest to, aby instytucje różnych modeli PS nie stały ze soba w sprzeczności i by przyczyniały się do uzyskania stabilności politycznej w wielosegmentowym państwie.

Elastyczność instytucjonalna HPS nie jest jednak bezgraniczna. Warto tu zwrócić uwage zwłaszcza na dwie kwestie. Po pierwsze, aby system polityczny miał charakter HPS nie wystarczy dodać do pierwotnie istniejącego modelu PS pojedynczej instytucji innego modelu PS. Gdyby bowiem, teoretycznie rzecz rozpatrując, do każdego centrypetalnego lub konsocjonalnego systemu politycznego dodano choćby jedna instytucję typowa dla drugiego $z$ tych modeli, wówczas każdy system polityczny typu PS miałby charakter HPS. Jeśli zatem np. do systemu centrypetalnego doda się tylko jedna instytucję konsocjonalna, nie ma sensu automatycznie uznawać go za system HPS, chyba że dodana instytucja pełni bardzo ważną rolę w całym systemie politycznym. Zwykle jednak do określania systemu politycznego mianem HPS powinna uprawniać większa liczba instytucji dodanych $z$ niedominującego modelu PS (lub, ewentualnie, instytucji hybrydowych).

Po drugie, aby jakiś system typu PS miał charakter HPS, przynajmniej jedna instytucja niedominującego modelu PS (lub, ewentualnie, instytucja hybrydowa) powinna funkcjonować na poziomie ponadregionalnym. Inaczej rzecz ujmując, instytucje różnych modeli PS powinny istnieć na poziomie całego państwa. Jeśli instytucje innego modelu PS niż dominujacy funkcjonowałyby tylko na poziomie regionalnym (np. jakaś prowincja państwa o systemie w przeważajacym stopniu centrypetalnym miałaby specjalna autonomię i mogłyby w niej działać partie etniczne), to wówczas klasyfikowanie takiego stanu rzeczy jako HPS wydaje się nieuprawnione.

Oba omówione zagadnienia wiążą się $z$ pytaniem o to, jakie minimalne kryteria instytucjonalne powinny uprawniać do określania danego systemu typu PS mianem hybrydowego. Być może warto zastosować jednocześnie dwa wskazane kryteria: liczby instytucji modelu PS innego niż dominujący i poziomu władzy, na którym występują. I tak, za HPS można zwłaszcza uznać taki system, w którym do konsocjonalizmu lub centrypetalizmu zostało dodanych kilka instytucji innego modelu PS, przy czym co najmniej jedna taka instytucja występuje na poziomie całego państwa. Tak jest w przypadkach: Nigerii, Indonezji, Kenii i Burundi. 


\section{UWAGI KOŃCOWE}

HPS to dotychczas najsłabiej przebadany i steoretyzowany spośród głównych modeli PS. Artykuł ten powinien przyczynić się do zmiany tego stanu rzeczy. Przedstawiłem w nim i omówiłem podstawowe założenia koncepcyjne i instytucje HPS na tle szerszej teorii PS. Zidentyfikowałem je na podstawie analizy empirycznych przypadków Nigerii, Indonezji, Burundi i Kenii. Celem tej analizy jest rozwój teorii HPS, potrzebny $z$ wielu powodów. Przynajmniej dwa warto tu wymienić.

Po pierwsze, HPS jest modelem silnie osadzonym $w$ praktyce i zarazem oddolnym, by nie rzec żywiołowym. Łaczy bowiem w sobie założenia koncepcyjne i instytucje o charakterze centrypetalnym, konsocjonalnym i hybrydowym bez dokładnego ustalania, ile instytucji i które $z$ nich musi zawierać. Jak wykazuję, sztywnych założeń HPS jest zaledwie kilka. Sa one niezbędne do wyodrębnienia modelu ogólnego. Warto jednak podkreślić, że w przypadku HPS, tak jak i innych modeli PS, najważniejsze nie jest to, by każdy przypadek empiryczny był $\mathrm{w}$ pełni zgodny z założeniami koncepcyjnymi modelu. Co więcej, zmieniające się realia konkretnych kazusów HPS moga przecież modyfikować niektóre założenia leżace u podstaw teorii HPS. Najistotniejsze jest zaś to, by HPS skutecznie ograniczało konflikty i stabilizowało sytuację polityczną w państwie, w którym funkcjonuje i, w konsekwencji, by służyło za przykład możliwy do zastosowania w jakimś stopniu w innych państwach. Teoria HPS może w tym względzie pełnić m.in. role: informacyjna, systematyzującą i edukacyjna.

Po drugie, w coraz większej liczbie państw wielosegmentowych, $\mathrm{w}$ tym wieloetnicznych, następuje naturalny proces hybrydyzacji ich systemów politycznych poprzez dodawanie do dotychczas funkcjonujacego modelu PS instytucji innego modelu PS. Proces ten kształtuje HPS. Procesowi hybrydyzacji w stopniu większym od centrypetalizmu zdaje się podlegać konsocjonalizm ${ }^{64}$. Przekształcanie lub wręcz zanikanie konsocjonalizmu może następować zwłaszcza w warunkach budowy tożsamości narodowej w społeczeństwie wielosegmentowym. I tak, np. Francja wieki temu była państwem składającym się $z$ wielu grup etnicznych władających różnymi językami. Dzisiaj ma po prostu lokalne mniejszości etniczne, jak np. Korsykanów, których język i inne elementy kulturowe nigdy nie zanikły. Ogólnie rzecz bioracc,

${ }^{64}$ Por. B. Reilly, Political Reform and the Demise of Consociationalism in Southeast Asia, Perth 2011, s. 4-5, 18-19. 
proces budowania tożsamości narodowej Francuzów był jednocześnie procesem zanikania tożsamości segmentowych ${ }^{65}$. Co prawda, konsocjonalizm nigdy we Francji nie funkcjonował, ale analogicznie do jej historycznego przykładu $z$ dużym prawdopodobieństwem można założyć, że proces zmniejszania znaczenia tożsamości segmentowych postępuje w wielu współczesnych państwach wieloetnicznych. Istnienie $\mathrm{w}$ nich systemu konsocjonalnego może ten proces opóźnić, gdyż instytucje konsocjonalne moga na pewien czas wzmacniać tożsamości etniczne. Nie musi mu jednak zapobiec. Można zatem założyć, że konsocjonalizm będzie w niektórych państwach $z$ czasem zanikał na rzecz liberalnego systemu politycznego demokracji większościowej, systemów politycznych funkcjonujących zwłaszcza w warunkach reżimów (quasi-)autorytarnych, a także na rzecz HPS lub centrypetalnego PS. HPS i centrypetalizm moga przy tym, choć nie musza, pełnić rolę tymczasowych systemów politycznych.

Oczywiście zanik konsocjonalizmu może mieć charakter raptowny i dramatyczny, tak jak stało się to np. w Rwandzie w 1994 r., gdy został on zlikwidowany w warunkach tragicznego konfliktu ${ }^{66}$. Przykład Rwandy pokazuje, że diametralna zmiana charakteru systemu politycznego może nastapić nie tyle w wyniku długiego procesu, lecz nagłego fenomenu. Oczywiście wojna (lub inna gwałtowna okoliczność, jak np. rewolucja lub zamach stanu) nie musi prowadzić do zaniku konsocjonalizmu. I tak np. w Libanie długotrwała wojna domowa przyniosła korektę tamtejszego konsocjonalizmu ${ }^{67}$, a w przypadku Bośni i Hercegowiny wojna zakończyła się ustanowieniem systemu konsocjonalnego dla nowo powstającego państwa.

Zmiany systemu politycznego typu PS równie dobrze moga mieć charakter pokojowy. I tak, HPS może się rozwijać poprzez uzupełnianie dominującego konsocjonalizmu instytucjami centrypetalnymi (i hybrydowymi), jak choćby ma to miejsce w przypadku Burundi, albo też $\mathrm{w}$ drodze dodawania do dominującego centrypetalizmu instytucji konsocjonalnych (i hybrydowych), jak dzieje się to np. w Nigerii i Indonezji. Kazusy tych dwóch państw maja przy tym charakter

65 K. Trzciński, Obywatelstwo $w$ Europie. Idea i jej wyraz formalny $w$ perspektywie historycznej, „Studia Europejskie” 2002, nr 2, s. 53, 60-61; K. Trzciński, Obywatelstwo $w$ Europie. $Z$ dziejów idei i instytucji, Warszawa 2006, s. 197-198.

66 S. Vandeginste, Governing Ethnicity after Genocide: Ethnic Amnesia in Rwanda versus Ethnic Power-Sharing in Burundi, „Journal of Eastern African Studies” 2014, t. 8, nr 2, s. 263-277.

${ }^{67}$ Zob. szerzej np. N. Bahlawan, Nowe ruchy społeczne wobec systemu politycznego w Libanie..., zwłaszcza s. 59-67. 
szczególny, gdyż po uzyskaniu niepodległości istniały w nich nieliczne instytucje konsocjonalne (w Nigerii - etniczny federalizm i partie etniczne; w Indonezji - partie etniczne i religijne) ${ }^{68}$, które $z$ czasem zaczęły być zastępowane (lub uzupełniane) instytucjami centrypetalnymi (i hybrydowymi). Gdy zaś centrypetalizm wyparł (niepełny) konsocjonalizm, to wówczas rozpoczął się proces odwrotny - do instytucji centrypetalizmu zaczęły być dodawane instytucje konsocjonalne. Za każdym razem następował proces hybrydyzacji dominującego modelu PS, wpierw niepełnego konsocjonalizmu, a następnie centrypetalizmu.

Oznaki hybrydyzacji systemów politycznych typu PS sa współcześnie zauważalne $\mathrm{w}$ mniejszym lub większym stopniu również $\mathrm{w}$ wielu innych wielosegmentowych państwach lub regionach, w tym m.in. w Bośni i Hercegowinie, Libanie, Malezji i Irlandii Północnej. Gdyby zaś dogłębnie przebadać naturę systemów politycznych typu PS różnych państw wielosegmentowych, zapewne w większości $z$ nich można by znaleźć choćby pojedynczą instytucję innego modelu PS niż ten, który jest dla nich charakterystyczny. A to mogłoby świadczyć o początku hybrydyzacji ich systemów.

Badanie pokojowej hybrydyzacji systemów politycznych, włączając systemy typu PS, jest potrzebne, ponieważ proces ten może stanowić alternatywna propozycję wobec siłowej odpowiedzi na zmiany rzeczywistości społecznej, politycznej i ekonomicznej w państwach wielosegmentowych. Taki zamysł legł również u podstaw badań, których owocem jest ten artykuł.

68 J. Bertrand, Nationalism and Ethnic Conflict in Indonesia, Cambridge 2004, s. 52-53; D.L. Horowitz, Constitutional Change and Democracy in Indonesia, New York 2013, s. 49; K. Trzciński, Ograniczanie konfliktów w Nigerii i Indonezji..., s. 66-67. 